\title{
The Effect Of The Application Of Play Therapy On The Anxiety Level Of Children Experiencing Hospitalization Reactions In Pre-School Age Children At Rsud Haji Provinsi Sulawesi Selatan
}

\author{
Harnilawati $^{1^{*}}$, Asrianto $^{2}$ \\ Nursing Science Study Program Yapika Institute of Health Sciences Makassar, Indonesia ${ }^{12}$ \\ *Correspending Author : \\ Email : nilawatimerah@gmail.com
}

\begin{abstract}
When hospitalized, children have to be left behind by their loved ones, family and friends that it causes anxiety to the children. In addition to anxiety caused by separation, children can also experience anxiety due to losing control of themselves. The implementation of Play Therapy is part of child care and one of the effective interventions for children. The purpose of the study is to determine the effect of the application of Play Therapy on reducing anxiety in pre-school age children at RSUD Haji Provinsi Sulawesi Selatan. The research method used was Quasy experiment with a pre-test and post-test control group approach. The subjects in this study were pre-schoolers with a total sample of 40 people consisting of 20 people in the treatment group and 20 people in the control group with the determination of the sample using consecutive sampling. The instrument used to measure the level of anxiety was the Hamilton Anxiety Rating Scale (HARS), while the intervention was in the form of Play Therapy, especially drawing and coloring games. The results showed that the Wilcoxon Signed Rank Test statistical test in the treatment group obtains a significant value of $p=0.000$, smaller than $\alpha=0.05$, which means that there are differences in anxiety levels from the results of the pre-test and posttest. Meanwhile, in the control group, a significant value of $p=0.480$ is obtained, which is greater than $\alpha=0.05$, meaning that there is no difference in the level of anxiety from the results of the pre-test and post-test.
\end{abstract}

Keywords: Anxiety Level, Hospitalization, Preschool Age Children, Play Therapy

\section{INTRODUCTION}

Hospitalization is a process that occurs due to a planned or emergency reason that requires children to stay in the hospital to undergo treatment and care until they return home, where this is a big problem that can cause fear and anxiety to children [1]. Preschool age children are the ones aged between 3 to 6 years that most of them can understand such a complex language.[2] Nearly four million children in one year experience a reaction to hospitalization where $6 \%$ are under the age of 18 . Sick children need special care compared to other patients because children have special features and characteristics that need to be seen. Children are not miniatures of adults or small adults. Moreover, the time needed to treat children is $20-45 \%$ more than the time needed to care for sick adults [3]. Hospitalization can cause stress and anxiety at any age. The unidentified fear can threaten the psychology of every one who is hospitalized, including hospitalized children. Children are too young to understand what is happening or are too afraid to ask questions [4]. The higher the level of pain felt by the patients, the higher the impact of hospitalization felt by them. This situation often occurs in both preschool and school age children because children still lack of knowledge about the concept of hospitalization. This is also because children are trying to adjust to the new environment, namely the hospital, so that these conditions can be a stressor factor for children, parents and families [5]. 
One of the interventions that can be carried out in hospitals to reduce the effects of this hospitalization reaction is to apply the play therapy, an activity in carrying out nursing care which is very important to reduce negative psychological effects for the growth and development of children in the future [6]. Anxiety will be reduced if the children feel comfortable, safe and ready to accept new situations and conditions. This sense of comfort and security can be obtained by children through a game-based method.Based on an initial survey conducted in the pediatric ward of RSUD Haji Provinsi Sulawesi Selatan in October 2020, around 78\% of the treated children showed a reaction to hospitalization. Meanwhile, from the results of interviews with nurses, it was found that the play therapy program had never been implemented in the hospital. Therefore, in the absence of a play therapy program at RSUD Haji Provinsi Sulawesi Selatan, we were interested in conducting a research about "The Effect of the Application of Play Therapy on the Anxiety Level of Children Experiencing Hospitalization Reactions in Pre-School Age Children at RSUD Haji Provinsi Sulawesi Selatan."

\section{METHODS}

The research method used was the Quasy experiment with a pre-test and post-test control group approach. The research was carried out starting from February to September 2021 at the General Hospital Haji, South Sulawesi. The subjects in this study were pre-school age children who were being treated with a total sample of 40 people consisting of 20 people in the intervention group and 20 people in the control group with the determination of the sample using consecutive sampling. The intervention group was given a treatment in the form of play therapy, especially drawing and coloring conducted for 30 minutes, while the control group was not given any treatment. The instrument used to measure the level of anxiety in preschoolers was the Hamilton Anxiety Rating Scale (HARS).

\section{RESEARCH RESULT}

\section{Characteristics of Respondents}

Table 1.1. Frequency Distribution of Respondents Characteristics at RSUD Haji Provinsi Sulawesi Selatan 2021

\begin{tabular}{|c|c|c|c|c|}
\hline \multirow[t]{2}{*}{ Characteristics } & \multicolumn{2}{|c|}{$\begin{array}{c}\text { Treatment } \\
\text { Group }\end{array}$} & \multicolumn{2}{|c|}{$\begin{array}{c}\text { Control } \\
\text { Group }\end{array}$} \\
\hline & $\mathbf{N}$ & $\%$ & $\mathbf{N}$ & $\%$ \\
\hline \multicolumn{5}{|l|}{ Gender } \\
\hline Male & 9 & 45 & 8 & 40 \\
\hline Female & 11 & 55 & 12 & 60 \\
\hline Total & 20 & 100 & 20 & 100 \\
\hline \multicolumn{5}{|l|}{ Age } \\
\hline 3-4 years old & 7 & 35 & 10 & 50 \\
\hline 5-6 years old & 13 & 65 & 10 & 50 \\
\hline Total & 20 & 100 & 20 & 100 \\
\hline
\end{tabular}

Table 1.1 can be explained that in the treatment group, most of them are female, consisting of 11 people (55\%). This case also applies in the control group where female respondents are 12 people (60\%). Meanwhile, 13 children dominate the age characteristics where most of the them are children aged 5-6 years (65\%) in the treatment group, while in the control group there are 10 respondents (50\%) aged 3-4 years and 5-6 years respectively.

2. Frequency distribution of anxiety level during the Pre test - Post Test of the treatment group

Table 1.2. Frequency Distribution of the Pre Test - Post Test of the Treatment Groups at RSUD

Haji Provinsi Sulawesi Selatan in 2021

\begin{tabular}{cccccc}
\hline \multirow{2}{*}{$\begin{array}{c}\text { Anxiety } \\
\text { level }\end{array}$} & $\mathbf{N}$ & Pre test & \multicolumn{2}{c}{ Post test } \\
\cline { 2 - 5 } & 0 & 0 & 8 & $\%$ \\
\hline None & & 0 & 40 \\
\hline
\end{tabular}

$\underline{\text { http://ijstm.inarah.co.id }}$ 


\begin{tabular}{ccccc}
\hline Mild & 5 & 25 & 9 & 45 \\
Moderate & 8 & 40 & 2 & 10 \\
Severe & 7 & 35 & 1 & 5 \\
Total & 20 & 100 & 20 & 100 \\
\hline
\end{tabular}

The data in table 1.2 show that before the play therapy treatment is carried out, there are 7 respondents (35\%) with severe anxiety, 8 respondents (40\%) with moderate anxiety and 5 respondents $(25 \%)$ with mild anxiety. After the play therapy treatment, there is a decrease in the level of anxiety where 8 respondents $(40 \%)$ have no more anxiety, 9 respondents (45\%) experience mild anxiety, 2 respondents $(10 \%)$ experience moderate anxiety and 1 respondent (5\%) experiences severe anxiety.

3. Frequency distribution of anxiety level of the Pre test - Post Test of the control group

Table 1.3. Frequency Distribution of the Pre test - Post Test of the control group at RSUD Haji Provinsi Sulawesi Selatan in 2021

\begin{tabular}{ccccc}
\hline Anxiety & \multicolumn{3}{c}{ Pre test } & \multicolumn{3}{c}{ Post test } \\
\cline { 2 - 5 } level & $\mathbf{N}$ & $\mathbf{\%}$ & $\mathbf{N}$ & $\mathbf{\%}$ \\
\hline None & 0 & 0 & 0 & 0 \\
Mild & 5 & 25 & 3 & 15 \\
Moderate & 10 & 50 & 12 & 60 \\
Severe & 5 & 25 & 5 & 25 \\
Total & 20 & 100 & 20 & 100 \\
\hline
\end{tabular}

The data in table 1.3 show the number and percentage after the pre-test where each of 5 respondents $(25 \%)$ experiences severe anxiety and mild anxiety and 10 respondents (50\%) with moderate anxiety. After conducting the post-test, it is found that 3 respondents (15\%) have mild anxiety, 12 respondents $(60 \%)$ have moderate anxiety and 5 respondents $(25 \%)$ have severe anxiety.

\section{Frequency distribution of Wilcoxon Signed Rank Test analysis test}

Table 1.4. Distribution of the frequency of the Wilcoxon Signed Rank Test analysis test at RSUD Haji Provinsi Sulawesi Selatan in 2021

\begin{tabular}{lcccc}
\hline & \multicolumn{2}{c}{ Treatment Group } & \multicolumn{2}{c}{ Control Group } \\
& Pre Test & Post Test & Pre Test & Post Test \\
\cline { 2 - 5 } Mean & 3.10 & 1.80 & 3 & 3.10 \\
Minimum & 2 & 1 & 2 & 2 \\
Maximum & 4 & 4 & 4 & 4 \\
SD & 0.788 & 0.834 & 0.725 & 0.641 \\
Wilcoxon Signed Rank Test & \multicolumn{2}{c}{$\mathrm{P}=0.000$} & \multicolumn{2}{c}{$\mathrm{P}=0.480$} \\
\hline
\end{tabular}

Based on table 1.4 above, the results of the Wilcoxon Signed Rank Test statistical test in the treatment group obtain a significant value of $\mathrm{p}=0.000$ smaller than $\alpha=0.05$, so the hypothesis is accepted, meaning that there is a significant difference in anxiety levels from the results of the pre-test and post-test. Meanwhile, in the control group, a significant value of $\mathrm{p}=0.480$ is obtained, greater than $\alpha=0.05$, so the hypothesis is rejected, meaning that there is no difference in the level of anxiety from the results of the pre-test and post-test in the control group.

\section{DISCUSSION}

\section{The level of anxiety of Pre test - Post test of the treatment group}

The results of the study based on table 1.2 in the treatment group before the play therapy is carried out show that out of 20 respondents there are 8 respondents who (40\%) experience moderate anxiety, 7 respondents (35\%) experience severe anxiety and others experience mild anxiety. Children who experience severe anxiety look restless, show tense facial reactions, cry, and avoid new people. This is in accordance with the theory of Stuart and Sundeen (2016) who stated that anxiety was an emotional state without a specific object. This was caused by something unknown and also because all experiences were new to the child [7]. This discussion is in 
accordance with the observations of researchers at the time of the study. Child's anxiety can be seen before play therapy intervention is given where most children do not want to be left by their parents. Sometimes the children cry, are afraid to see new people, and do not want to be separated from their closest people. It makes children who are hospitalized mostly experience moderate anxiety. Stress due to illness usually makes children less able to deal with separation. As a result, they show a lot of anxious and protesting behaviora (Supartini, 2012). Preschool children are not able to accept the perception of illness and the unfamiliar environment of the hospital [8].The results of the study in table 1.2 show the level of anxiety in preschoolers before being given coloring play therapy. There is 1 respondent who experiences severe anxiety (5\%), 2 respondents experience moderate anxiety $(10 \%), 9$ respondents experience mild anxiety (45\%) and 8 respondents $(40 \%)$ do not experience anxiety. From these results, it can be seen that the anxiety of most of the respondents decreases. Moreover, there are 8 respondents $(40 \%)$ who have no anxiety.

The results in this study are in line with Hartini (2019) who stated that after coloring pictures therapy was carried out, it was found that $86.1 \%$ or most of the children were not anxious. It shows that there is an increase for $63.9 \%$ after the coloring therapy. From the results obtained, it is concluded that most of the 50 children feel accepted as they are, value their uniqueness, and feel psychologically safe after being given play therapy. As a result, after the intervention is carried out in the study, there is an average increase in children's anxiety. Overall, there is a tendency to decrease anxiety levels in the treatment group between before and after being given play therapy [9]. This situation is because the character of each children has different stressor factors. This is also in line with the research conducted by Pratiwi (2012) that children who were hospitalized experienced an anxiety response, but after being given play therapy, the level of anxiety decreased from severe anxiety to moderate anxiety, and those with moderate anxiety decreased to mild anxiety. Then, in mild anxiety that initially had three or two symptoms the level decreases to two or one symptom. This shows a very significant reduction in anxiety [10]. It is proven that the game-based method is able to reduce anxiety levels as the research conducted by Subardiah (2009) whose results showed that games were able to reduce anxiety levels. [11].

\section{2. $\quad$ The level of anxiety of the Pre test-Post Test of the control group}

Table 1.3 shows that after the pre-test, each of 5 respondents $(25 \%)$ has severe anxiety and mild anxiety, and 10 respondents $(50 \%)$ have moderate anxiety. After conducting the post-test, it is found that 3 respondents $(15 \%)$ have mild anxiety, 12 respondents $(60 \%)$ have moderate anxiety and 5 respondents $(25 \%)$ have severe anxiety. From these results, it is found that there are 2 respondents who experience an increase in anxiety after the post-test, who, based on the results of the researcher's observations, are 3-year-old patients. In this case, the researcher assumes that the younger the child is, the more difficult it will be for him to adjust to the new experience of being hospitalized for the first time. According to Supartini (2012), children's reactions to illness varied according to the level of child development. [8]. This is in accordance with the results of Dewi's research (2018) that anxiety could be influenced, one of which was the age factor, because age was closely related to the level of cognitive development of a child. The younger the child, the higher the anxiety experienced. [12].

\section{3. $\quad$ Wilcoxon Signed Rank Test analysis test results}

Based on the results of the Wilcoxon Signed Rank Test statistical test in the treatment group, $\mathrm{p}=0.000<$ $\alpha=0.05$ means that there is a significant difference in the category of children's anxiety levels before and after the play therapy at RSUD Haji Provinsi Sulawesi Selatan. While in the control group, a greater significance value of $\alpha=0.05$ is obtained, so the hypothesis is rejected. There is no significant difference in anxiety level scores from the results of the pre-test and post-test in the control group. These results indicate that play therapy in the form of picture coloring games can indeed reduce anxiety levels. These results are in line with several previous studies that have proven the effectiveness of play therapy in reducing anxiety levels. One of them is a study conducted by Katinawati (2011) which showed that there was an effect of play therapy on the anxiety level of children treated at Rumah Sakit Umum Tugu Rejo, Semarang with p value $=0.000$ [13] as well as the 
research by Mujiastuti (2009) on the effect of play therapy to the anxiety in pre-school age children (3-5 years) in the Anggrek ward of the Saras Husada Hospital, Purwekorto in 2009, with the Paired t-test.

The results showed the average value of anxiety before being given playing therapy treatment was 14 with a standard deviation of 5, while the average anxiety after being given playing therapy treatment was 11 with a standard deviation of 3 , where $p$ value $=0.000$ and the value $(p<0.05)$ [14]. The effectiveness of play therapy is in accordance with what was said by Wong (2009), stating that the forms of games that were suitable for preschool age children included playing puzzles, playing simple games, playing music, role playing, listening to stories (fairy tales), observing picture books, drawing and coloring pictures [15]. In this study the researcher chooses play therapy coloring pictures. Coloring is a game that gives children the opportunity to freely express themselves and was very therapeutic (Paat, 2010) [16]. The use of coloring play activities as a therapy is based on the assumption that coloring pictures is a form of communication with children who are experiencing pain. This therapeutic activity even provides a way to express thoughts and feelings more safely than verbal communication (Malchiodi, 2003) [17]. Coloring activities also could create feelings of interest and fun in children and provoke their participation because in this therapy process children do something, not only engage in conversation (Muchtar \& Noor, 2006). Sometimes children feel annoyed with a lot of talking. In contrast to coloring pictures, someone has unconsciously expressed feelings of sadness, depression, stress, which creates images that make a person feel happy again and evoke the good times that have been experienced with loved ones (Aziz, 2009). 19]. Through this activity, children can divert their pain (distraction) and get a relaxing effect through their enjoyment of playing games (Wong, 2009) [15].

\section{CONCLUSION}

1. The results show that in the treatment group, before the play therapy is carried out, from 20 respondents, 8 respondents $(40 \%)$ experience moderate anxiety, 7 respondents $(35 \%)$ experience severe anxiety and others experience mild anxiety. Then, after being given coloring play therapy 1 respondent experiences severe anxiety (5\%), 2 respondents experience moderate anxiety (10\%), 9 respondents experience mild anxiety (45\%) and 8 respondents $(40 \%)$ do not experience anxiety.

2. The results show that in the control group, after conducting the pre-test, 5 respondents in a row $(25 \%)$ have severe anxiety and mild anxiety, and 10 respondents (50\%) have moderate anxiety. After conducting the post-test, it is found that 3 respondents (15\%) have mild anxiety, 12 respondents $(60 \%)$ have moderate anxiety and 5 respondents $(25 \%)$ have severe anxiety.

3. There is an effect of the application of play therapy on reducing the anxiety level of preschool aged children who experience a reaction to hospitalization at RSUD Haji Provinsi Sulawesi Selatan. Also, there is a significant difference in the level of anxiety in the treatment group and the control group.

\section{REFERENCES}

[1] Setiawan, D (2014) "Keperawatan Anak dan Tumbuh Kembang", Nuha Medika : Yogyakarta.

[2] Supartini, Y (2004) "Konsep Dasar Keperawatan Anak ", EGC : Jakarta

[3] Murniasih E \& Andika R (2007) "Hubungan Dukungan Keluarga dengan Tingkat Kecemasan Akibat Hospitalisasi pada Anak Usia Pra Sekolah di Bangsal 1 RSUP Dr. Soejarwadi Tirtonegoro Klaten" Jurnal Kesehatan Surya Medika Yogyakarta.http://www.google.co.id. Retrieved on 02 Oktober 2010.

[4] Manurung, S (2011) "Asuhan Keperawatan Intranatal", Trans Info Media : Jakarta Timur.

[5] Bobak et all (2004) "Buku Ajar Keperawatan Maternitas Edisi 4", EGC : Jakarta.

[6] Nursalam, Susilaningrum, R \& Utami (2005) "Asuhan Keperawatan Bayi dan Anak ", (untuk Perawat dan Bidan ), Salemba Medika : Jakarta

[7] Stuart \& Sudeen. (2016), Buku Saku Keperawatan Jiwa Jakarta:EGC

[8] Supartini, Y. (2012). Buku Ajar Konsep Keperawatan Anak. Jakarta: EGC. 
[9] Hartini, Sri dkk. (2019). Perbedaan Tingkat Kecemasan Anak Usia Prasekolah Saat Hospitalisasi Sebelum Dan Setelah Dilakukan Terapi Bermain Mewarnai Gambar Di Ruang Bogenvile RSU Kudus. Jurnal Keperawatan dan Kesehatam Masyarakat. Kudus: Program Studi Ilmu Keperawatan. STIKES Cendekia Utama Kudus.

[10] Pratiwi, Y. (2012). Pengaruh Terapi Bermain Terhadap Respon Kecemasan Anak Usia Pra Sekolah Di Ruang Perawatan Anak RSUD Syekh Yusuf Kabupaten Gowa. Jurnal UIN Alaudin Makassar Repository. Makassar. Jurusan Keperawatan. Fakultas Ilmu Kesehatan. Universitas Islam Negeri Alaudin Makassar.

[11] Subardiyah, I.P. (2009). Pengaruh permainan terapeutik terhadap kecemasan, Kehilangan kontrol, dan ketakutan anak prasekolah selama dirawat di RSUD Dr. H. Abdul Moeloek Propinsi Lampung. [Skripsi]. Fakultas Ilmu Keperawatan Universitas Indonesia.

[12] Dewi Permata, D. A. I. (2018). Pengaruh Terapi Bermain Plastisin Terhadap Penurunan Kecemasan Akibat Hospitalisasi Pada Anak Usia Prasekolah (3-6 tahun). Jurnal STIKES Insan Cendekia Medika Repository. Jombang. Program Studi S1 Ilmu Keperawatan. STIKES Cendekia Medika.

[13] Katinawati, Handayani S, Ari.S. 2011. Pengaruh Terapi Bermain Dalam Menurunkan Kecemasan Pada Anak Usia Pra Sekolah Yang Mengalami Hospitalisasi di RSUD Tugurejo Semarang.

[14] Mujiastuti U. Pengaruh Terapi Bermain Terhadap Kecemasan Pada Anak Usia Pra Sekolah (3-5 tahun) di Bangsal Anggrek RSUD Saras Husada Purwekorto Tahun 2009, Skripsi.http://www.terapi bermain.com. Retrieved on 10 Agustus 2021.

[15] Wong,D,L. (2009) . Buku Ajar Keperawatan Pediatrik. Edisi VI. Editor : Komara, EY, Jakarta : EGC

[16] Paat, T. C (2010). Analisis Pengaruh Terapi Bermain Terhadap Prilaku Kooperatif Pada Anak Usia Prasekolah (36 Tahun) Selama Menjalani Perawatan Di Ruangan Ester Rumah Sakit Umum Pancaran Kasih GMIM Manado : Universitas Sam Ratulangi. Retrieved on 02 Agustus 2021.

[17] Malchiodi, C. A. (2003). Handbook of Art Therapy. New York: Guilford Press.

[18] Mukhtar, Noor Rochman (2006). Efektivitas Art Therapy Untuk Meningkatkan Keterampilan Sosial Pada Anak Yang Mengalami Gangguan Perilaku. Psikologia.

[19] Alimul Hidadayat, Aziz (2009). Pengantar ilmu keperawatan anak 1. Jakarta : Salemba Medika 